\title{
Restrict, clean and protect: \\ Signalling consumer safety during the pandemic and beyond
}

\begin{abstract}
Purpose: Since the outbreak of the COVID-19 pandemic customers fear for their health when interacting with service providers. To mitigate this fear service providers are using safety signals directed to consumers and other stakeholders who make organizational assessments. The purpose of this article is to synthesize the range of safety signals in a framework that integrates signalling theory with servicescape elements so as to provide guidance for service providers to assist in their recovery.
\end{abstract}

Design/methodology/approach: We extracted examples of how service providers signal safety to their consumers that the risk of infection is low in exchanging with their service. These examples were taken from secondary data sources in the form of trade publications resulting from a systematic search and supplemented by an organic search.

Findings: In total 53 unique safety signals were identified and assigned to 24 different categories in our framework. Most of the signals fell into the default and sale independent category, followed by the default contingent revenue risking category.

Originality: This study builds on signalling theory and service literature to develop a framework of the range of safety signals currently in use by service providers and offers suggestions as to which are likely to be most effective. Further, a future research inquiry of safety signals is presented which we believe has promise in assisting recovery in a post pandemic world.

Keywords: Signalling theory, signals, risk perceptions, consumers, safety, COVID-19, coronavirus

Paper type Research paper 


\section{Restrict, clean and protect: Signalling consumer safety during the pandemic and beyond}

The COVID-19 pandemic has caused a sharp, steep economic shock and a profound disruption to all service industries. Some service industries such as cruising face a tough, if not impossible journey to win back customer confidence once restrictions are lifted. Other service industries such as restaurants and entertainment venues will still have to overcome the hurdle of fear that consumers will have in judging whether their venues are safe. This is especially true of collective consumption contexts (Kuppelwieser and Finsterwalder, 2011), settings within which multiple consumers and service personnel are co-present (physically) and coordinate with one another during the process of service consumption (Kelleher et al., 2019). Without the certainty of safety it is likely that governments will not ease social restrictions, and some consumers will freeze in indecision, or avoid the service altogether as has been witnessed in the city of Wuhan at the end of the lockdown where residents continue to avoid restaurants as they are gripped by the fear of reinfection (Chen and Che, 2020).

We look to signalling theory (Spence, 1974) as a way forward in offering service providers strategies to overcome consumer fear during and after the pandemic. This is because signals as perceivable indicators of otherwise hidden qualities which consumers can interpret and act upon (Bergh et al., 2014), offer the potential to reduce consumer uncertainty and to foster purchase decisions regarding the seller (Bente et al., 2012). Note that we apply the word signal for those stimuli that are meant to serve as intentional communication by the service provider. That is, deliberate communication of positive information by the service provider in an effort to convey desirable imperceptible attributes (Connelly et al., 2011). Thus, a cue acts as a signal only if it is intentionally communicative, and its goal "is to alter the receiver's beliefs or behaviors in ways that benefit the signaler" (Donath 2011, p. 3). 
Typical marketing signals have included brand name and seller reputation systems (Bente et al., 2012; Yen, 2006). However, whereas in pre-COVID-19, consumers' concerns were about the seller's credibility to deliver upon the promise (e.g., performance risk; Jacoby and Kaplan, 1972), now the informational gap is around the physical risk of asymptomatic transmission from both front-line staff and/or other customers who will share the service. As the virus presence is not directly observable, high information asymmetry exists as to how safe it is to exchange with the service provider. Consumers therefore rely on available signals, all perceivable features and actions put in place by the service provider that reflect the absence of the virus, to make inferences about the service provider's safety. Thus, our research question is: What types of signals have service providers used to reduce consumer perceptions of physical risk in a COVID-19 era? This is important, as the different types of signals can convey diverse messages (Bokek-Cohen, 2015), and have varied effects and relevance for the different types of consumer perceived risks (Biswas and Biswas, 2004).

To answer this research question, we combine a theory- and data-driven approach. We develop a framework of the various safety signals available to service providers by integrating Kirmani and Rao’s (2000) typology with servicescape elements to categorize safety signals used in practice. In doing so we contribute in two ways to the service literature. First, we extend Kirmani and Rao’s (2000) marketing quality signals typology and granulize it, so that the nature of safety signals is further distinguished to facilitate investment and implementation considerations. Second, we set a research agenda for future inquiry into safety signals, the answers which we believe will assist service providers in their recovery in a post pandemic world.

\section{Signalling theory}


During the COVID-19 pandemic and beyond as consumers are faced with incomplete and asymmetrically distributed information regarding the safety of a service provider, they will seek out signals, observable signs that provide information about unobservable attributes and likely outcomes (Spence, 1974). Signalling theory provides an explanatory basis as the use of signals can contribute to the creation of separating equilibrium, allowing customers to navigate information problems to best meet their objectives (Bergh et al., 2014). Therefore, a signal is effective if it allows consumers to distinguish between - or separate - the high- from low- quality service providers (Bergh et al., 2014), or in our case separate safe service providers from those deemed to be risky.

The typology by Kirmani and Rao (2000) classifies marketing signals into two major categories. First, default-independent signals incur expense for the service provider regardless of the truth of the claim. There are two types of "default-independent" signals: (1) sale-independent, where signals incur expenditure independent of anyone purchasing the service (e.g., paying for advertisements, presence of physical store, etc), and (2) salecontingent where signals incur expenditure only when a purchase occurs (e.g., low introductory price). This distinction is important as signals which involve up-front expenditure are cash intensive which is problematic for service businesses that have had to close or reduce their trading hours during the pandemic. Sales-independent signals also incur opportunity costs of pursuing another activity that may contribute to the service provider's recovery.

The second major category of marketing signals is known as default-contingent signals, where the service provider will only incur an expense if it defaults on its claim of quality (Kirmani and Rao, 2000), or in our case safety. These types of signals do not require any monetary expenses at the time of transmission. Again there are two types of defaultcontingent signals: (1) revenue-risking signals which ties future revenue to the firm's claim 
(e.g., high price), and (2) cost-risking signals where the firm only incurs a cost if it defaults on its claim (e.g., free warranty).

Signal confirmation occurs when the expected quality of the signal is realized through subsequent customer experience (Bergh et al., 2014). However, in terms of safety this validation process is challenging, as disconfirmation relies on customers or their friends becoming infected and visibly ill and being able to trace it back to the focal service provider. Alternatively, they become aware of infections originating from the service provider from the press.

\section{Servicescape elements}

Although Kirmani and Rao's (2000) typology is useful in guiding service providers into decisions based on the need for upfront investment and risk of failure, it does not offer sufficient breakdown on the range of signals that service providers can use. Given this limitation we focus on servicescape elements where signals can be employed.

Signals can be used at various customer touchpoints in the physical or virtual domain. First, service is "activated" through customers gaining access to the servicescape (Fließ and Kleinaltenkamp, 2004; Moeller, 2008) which offers one potential area where safety signals can be introduced. Second, following Bitner (1992) we differentiate signals that may be used as part of the immovable physical environment such as the hotel or retail store building, from those used as part of the more movable tangibles e.g., the bedsheets, the cutlery, the packaging. As the servicescape framework was later expanded by Rosenbaum and Massiah (2011) to include social elements, such as staff and other customers, we also include these as potential sources of safety signals. Last, service providers can use communication about the servicescape to signal safety. Thus, the integration of the servicescape medium for propagating the signal with Kirmani and Rao's (2000) typology makes for a more 
informative categorization of the types of safety signals available, their risk and required investment.

\section{Method}

Qualitative research is useful in an emerging empirical context (Witell et al., 2020) and often uses existing theory as a basis for interpreting data, to gain new insights to the phenomenon under investigation (Bansal and Corley, 2012). Since our study seeks to uncover signals currently used by service providers to communicate safety to consumers, we use content analysis as elaborated below (Abbott and McKinney, 2013).

To identify suitable activities that service providers have undertaken to send observable signals to consumers to communicate an unobservable safety attribute, we conducted both a systematic and an organic search. In a first step of the systematic search an initial list of articles was generated through the ProQuest database using the following three search terms: coronavirus, customers and safety, which had to appear in the article at the same time. We restricted our search to articles where an English full text was available, that appeared in the period between the $1^{\text {st }}$ of January 2020 to the $22^{\text {nd }}$ of April 2020 in global trade publications, magazine articles, and newsletters, excluding publications titles likely less relevant such as Energy, Telecom or Footwear News. Consistent with Abbott and McKinney's (2013) advice, we thought carefully on how to narrow down the sheer amount of material. Therefore, we excluded newspapers under the assumption that if a safety activity had relevance it would be reported in a trade magazine, since these are the sector specific specialised outlets. In total this search approach generated 818 articles. In a second step, we screened these articles by looking at the three keywords (coronavirus, customers and safety) in their context i.e., the database showing the three words before and the three words after the keyword provided on the front page of the search engine. The screening was done by an 
independent and trained researcher who was unfamiliar with the research question. From this screening 24 articles consisting of 121 examples (many of them redundant) emerged.

The authors complemented this systematic search with an organic search using a) google with the above search terms and b) examples from various sources when either one of the authors was made aware of them during general media consumption. The organic search generated another 108 articles with a high level of example redundancy. Witell et al. (2020, p. 3) emphasize that a "researcher should try to achieve saturation of information" even though this "is difficult to achieve". We agree and believe that this applies even more so in the case of a rapidly evolving empirical context such as ours.

An author assigned each example to one of the 24 a priori categories in the framework as shown in Table 1. Naturally there was some ambiguity in some of the examples. On few occasions a safety signal was assigned to more than one category as it communicated to multiple audiences. For example, "measuring customers temperature on access" may act as a signal to customers that they cannot enter the service if they are deemed at risk, but it may also act as a signal to other customers that the service factory will be safe. Thus, this signal was placed in two categories "access to servicescape" and "other customers." To ensure interrater reliability of the categorization of the safety signal examples, a second author randomly checked $20 \%$ of the examples (Benoit et al., 2017). Cohen's Kappa for inter-rater reliability was 0.85 and discrepant cases were discussed to reach consensus (Cohen, 1960).

\section{Results}

Table 1 below and its associated Web Appendix 1 show a number of interesting findings. First, the high number of different types of examples (53) illustrate that service providers seem to be creative and agile in generating and implementing innovative safety signals to their customers. Second, the high example redundancies during the analysis show that service providers mimic each other even across service sectors. Third, most of the 
examples were categorized as a sale-independent, default-independent signal (18). This is unsurprising given that these signals show commitment from the provider since they involve upfront costs. The second type of signal that was reported frequently was default-contingent signals for which the provider risks revenue (16). Some service providers obviously feel there is value is adopting such an approach, even though these types of signals are likely to be less efficient. For example, customers may be sceptical of the service provider's intention when no upfront costs are involved, or if the provider will actually honor the pledge of a warranty (Biswas and Biswas, 2004) due to the difficulty of laying blame to the contact point. Further, whilst the use of warranties as a signal to reduce performance risk makes sense, (as a service can be replaced, repeated, or the money refunded), it does not mitigate physical risk and reverse the damage of adverse selection should a customer be infected by COVID-19.

Examining the findings from a servicescape perspective, we note that access, tangibles and staff are three aspects where service providers have created and implemented the greatest variance in safety signals. Some of these signals can be viewed as 'imposed service innovations' (Heinonen and Strandvik, in press) as they highlight the strategic and progressive actions of service providers to make safety highly visible to consumers prior to purchase. Interestingly, we found that servicescape communication using 'safe' language such as the liberal use of words such as 'hygiene', 'disinfected' and 'clean,' increasingly dominated marketing communications as service providers re-opened for business. As Firshein (2020) confirms the most important word currently in the hospitality industry is 'clean'. 
Table 1: A framework for safety signals

\begin{tabular}{|c|c|c|c|c|c|c|c|}
\hline & & \multirow{2}{*}{ Access to servicescape } & \multicolumn{4}{|c|}{ Servicescape } & \multirow{2}{*}{$\begin{array}{l}\text { Communication } \\
\text { about servicescape }\end{array}$} \\
\hline & & & Physical environment & Tangibles & Staff & Other customers & \\
\hline \multirow{2}{*}{ 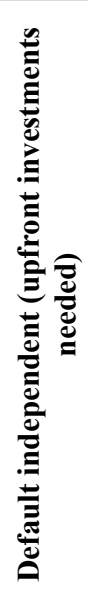 } & 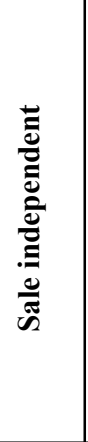 & $\begin{array}{l}\text { - Monitoring temperature, heart } \\
\text { and respiratory rate } \\
\text { - Booking platforms for walk-ins } \\
\text { - Curtailed shopping hours to } \\
\text { allow extra cleaning }\end{array}$ & $\begin{array}{l}\text { - Social distancing floor } \\
\text { stickers } \\
\text { - Increased level of } \\
\text { cleaning } \\
\text { - Provision of accessible } \\
\text { handwashing facilities } \\
\text { and/or hand sanitizer } \\
\text { - Design to minimize } \\
\text { contact with surfaces } \\
\text { e.g., hands-free door }\end{array}$ & $\begin{array}{l}\text { - Replacement of multi-use } \\
\text { boxes with disposable } \\
\text { packaging of deliveries } \\
\text { - Virus repellent fabrics } \\
\text { - Increased cleaning of items } \\
\text { customers touch } \\
\text { - Rollout of contactless } \\
\text { payment and check-in } \\
\text { facilities }\end{array}$ & $\begin{array}{l}\text { - Protective shields around high- } \\
\text { contact staff } \\
\text { - Regular testing, temperature } \\
\text { and traceability checks } \\
\text { - Provision of protective } \\
\text { equipment for staff e.g., gloves } \\
\text { and masks } \\
\text { - Introduction of virus detection } \\
\text { dogs } \\
\text { - Introduction of "germ- } \\
\text { zapping" robots } \\
\text { - Staff hygiene auditing }\end{array}$ & $\begin{array}{l}\text { - Monitoring } \\
\text { temperature, heart } \\
\text { and respiratory rate } \\
\text { - Provision of } \\
\text { protective equipment } \\
\text { for customers e.g., } \\
\text { gloves }\end{array}$ & $\begin{array}{l}\text { - Use of language } \\
\text { signaling safety }\end{array}$ \\
\hline & 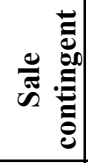 & $\begin{array}{l}\text { - Introduction of revised cleaning } \\
\text { protocols } \\
\text { - Contactless check-in }\end{array}$ & & $\begin{array}{l}\text { - Tamper evident seals for } \\
\text { deliveries } \\
\text { - Contactless digital menu }\end{array}$ & - Sanitize delivery staff & $\begin{array}{l}\text { - Protective shields for } \\
\text { customers } \\
\text { - Provision of health \& } \\
\text { safety kits } \\
\end{array}$ & \\
\hline \multirow{2}{*}{ 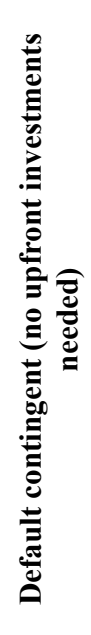 } & 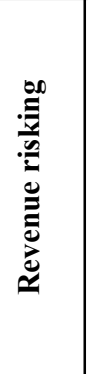 & $\begin{array}{l}\text { - Restriction on the number of } \\
\text { customers, e.g. one in, one out } \\
\text { policies } \\
\text { - Designated shopping hours for } \\
\text { key workers and vulnerable } \\
\text { customers } \\
\text { - Commencing or reducing } \\
\text { service portfolio to delivery } \\
\text { - Restrict customers access } \\
\text { depending on protection level }\end{array}$ & $\begin{array}{l}\text { - One-way isles to } \\
\text { manage traffic flow } \\
\text { - Removal of all } \\
\text { furniture to avoid } \\
\text { congregations }\end{array}$ & $\begin{array}{l}\text { - "Touch it, take it" policies } \\
\text { - Advice to customers to wash } \\
\text { and self-handle reusable bags } \\
\text { - Customer advice to self-swipe } \\
\text { card on payment } \\
\text { - Suspension of product } \\
\text { sampling }\end{array}$ & $\begin{array}{l}\text { - Removal of non-essential, } \\
\text { courtesy staff } \\
\text { - Leave at my door delivery } \\
\text { - Online only, no-counter } \\
\text { ordering }\end{array}$ & $\begin{array}{l}\text { - Advice not to bring } \\
\text { extra people into } \\
\text { stores } \\
\text { - Change in communal } \\
\text { sharing practices }\end{array}$ & $\begin{array}{l}\text { - In-store } \\
\text { announcements for } \\
\text { social distancing } \\
\text { - Best time to come } \\
\text { indication }\end{array}$ \\
\hline & 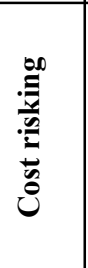 & $\begin{array}{l}\text { - Changing the way customers } \\
\text { access the service, e.g. middle } \\
\text { door of busses } \\
\text { - Delivery fee waiver for } \\
\text { vulnerable customers } \\
\text { - Extending opening hours }\end{array}$ & & $\begin{array}{l}\text { - Suspension customer items } \\
\text { entering the servicescape } \\
\text { - Suspension of reusable } \\
\text { programs } \\
\text { - Removal of items used in the } \\
\text { service process, e.g., baskets, } \\
\text { trays or magazines }\end{array}$ & $\begin{array}{l}\text { - Staff increased hand washing } \\
\text { routines } \\
\text { - Compensation to staff } \\
\text { including peer service } \\
\text { providers with positive } \\
\text { diagnosis }\end{array}$ & & \\
\hline
\end{tabular}




\section{Discussion}

Signalling theory offers a powerful explanatory framework for how service providers can navigate information uncertainties of consumers and the safety hazards associated with them. Our content analysis found the greatest variance of types of signals was in defaultindependent category. These signals require an up-front investment by the service provider and are more likely to be perceived as a commitment to customer safety (Kirami and Rao 2000). It has been suggested that voluntary signals that are more expensive to create and maintain (Donath 2007), have high up-front costs (Li et al., 2015), and are easy-to-verify (Mavlanova et al., 2012) are more likely to be perceived as credible evidence of an otherwise hidden quality, such as safety.

Further, different to the suggestion that visible physical cleaning actions such as deodorizing and sterilizing should be used to remove cues that would otherwise trigger contamination concerns (Hazée and Van Vaerenbergh, in press), we suggest that these actions act as safety signals. Once businesses open up consumers will likely expect service providers to use safety signals, and they will vigilantly scan the servicescape for these (Connelly et al., 2011). The absence of such signals will likely have a strong damaging effect on the seller than the type of safety signal used, due to an expectancy violation (see Burgoon, 1993). Also, past findings suggest that projecting multiple quality signals produce stronger risk-reducing and purchase-intention effects (Bente et al., 2012; Yen, 2006); thus the effects of multiple safety signals are also likely to be additive. When individual signals are taken in together by the customer, they will have the potential to create a powerful service providerlevel separating equilibrium. This said, interestingly, it appears as though the pandemic has annulled competitive pressures so that rather than focusing on the creation of a separating equilibrium, service providers are seeking to pool their efforts to sustain their industry. For example, a group of UK supermarkets have successfully demanded from the government to 
relax the competition laws to allow them to work together to "feed the nation" (GOV.UK, 2020).

Also, with respect to signal costs, these are inversely related to the reputational quality of the service provider (Bergh et al., 2014). We would expect low-quality service providers to have to invest at a level disproportionally higher than high-quality service providers to convey their safety message, as quality and safety share a symbiotic relationship (Love et al., 2015). Thus, whilst it may be optimal for high-quality service providers to signal to induce trial and reveal safety, for low quality sellers, a larger payoff is likely by adopting a non-signalling strategy (Kirmani and Rao, 2000; Li et al., 2015). For example, Mavlanova, Benbunan-Fich and Koufaris (2012) found that low-quality sellers avoided costly and easyto-verify website signals and used less fewer signals than high-quality sellers. Which relates to the consideration if a signal turns out to be false. Service providers who use signals e.g., floor stickers whilst doing nothing to ensure social distancing compliance will simply contribute to the separating equilibrium (Bergh et al., 2014), as customers will seek to punish them. Not only will customers likely employ sanctions, but they will spread negative e-WOM or call for regulatory action (Rao et al., 1999), making it easier for subsequent consumers to choose from the alternatives. Given such, we would expect the penalty costs of damaged reputation and future profits associated with false signalling to deter unsafe service providers from signalling (Rao et al., 1999). Notwithstanding this risk, if service providers perceive that the probability of detection is low and the penalty costs of deception are low, they may not care if their signal is fake or an exaggeration (Donath, 2007; Mavlanova et al., 2012).

Web Appendix 2 summarizes existing marketing signals identified in the literature post Kirmani and Rao's (2000) review, which have been used to communicate seller quality. It clearly demonstrates the lack of applicability of most of the signals to communicate safety. One quality signal with some level of transferability is the use third party endorsement or 
certification. For example, a service provider could cooperate with well-known cleaning product manufacturer to signal to customers that high-quality products are used to clean the servicescape. Since our content analysis, Dettol and Uber have partnered (https://www.uber.com/en-AU/newsroom/dettol/) and United Airlines announced an alliance with a cleaning product manufacturer (Clorox) and a Clinic (Cleveland Clinic) to signal safety to consumers (Calvey, 2020). In this latter example, consumers will rationally believe that the third parties (Clorox and Cleveland Clinic) have a unique ability to recognise cleanliness and would not endorse an unclean service provider (Rao et al., 1999). Relatedly, the NSW government of Australia has just launched a 'COVID Safe' digital badge and hygiene posters (https://www.nsw.gov.au/covid-19/covid-safe-businesses\#industries) that can be displayed by service providers who complete and demonstrate a safety plan tailored to their industry. What is interesting is that the market (consumer) can provide feedback on the accuracy of this safe signal (https://www.nsw.gov.au/give-feedback-on-a-business).

In summary, safety signals typically represent a cost and service providers will want to invest wisely in their choice of signals that will help drive their selection by consumers. Notwithstanding the type of signals that the service provider chooses to use, a key design imperative is that these signals are observable (Connelly et al., 2011) that is, perceptible and easy to access by potential customers.

\section{Limitations and future research}

Our study has limitations that open opportunities for further research. The timing of the systematic and organic search in April 2020 lead to results that are skewed towards examples from the grocery and food service sector. This is because these service providers are deemed essential (Collins, 2020) and have remained open during the lockdown. We believe that with time as other sectors re-open for business, they will develop some unique signals of their own 
so that Table 1 could be extended. Further, we excluded the healthcare sector since these service providers have always had to signal safety from infection.

We have focused on signals that can be used by service providers to reduce fears of virus infection in consumers, but service providers are also vulnerable to adverse selection and moral hazards associated with incomplete information about customers entering their servicescape as potential carriers of the virus. There has been the controversial suggestion of the introduction of an "immunity passport" or "risk-free certificate" which will be given to individuals who have recovered from COVID-19 on the assumption that they are now riskfree (WHO, 2020). This passport or certificate could be used by customers as a signal to flag their safety to service providers. However, it could be subject to abuse as two "classes" of customers might emerge, with one segment receiving priority access. If such were to occur, a black-market for fake immunity passports and certificates would result, negating the validity of the signal.

Also, this study has focused on the audience for safety signals being prospective customers. However, there are other stakeholders who make organizational assessments of safety. For example, the government seeks signals that the service provider is complying to social distancing regulations, and front-line staff seek signals that their workplace is safe (Tuzovic and Kabadayi, in press). Indeed, the Executive Vice President and CEO of Walmart U.S. indicated that the installation of sneeze guards was a way to bring peace of mind to both their employees and customers (Tyko, 2020). Thus, it would be interesting to understand which signals are most effective to communicate the message of safety to multiple audiences.

Moreover, although our search for safety symbols was neither restricted by country nor culture, it was confined to English communication which may have implicitly limited our exposure to signals used in non-English speaking countries. The role of culture is important 
to consider due to its impact on signal meaning which may be not be consistent leading to potential misinterpretations (Donath 2011). Further, the choice of signals in countries may be confined to what was readily available. For example, the use of hand-sanitizers at the point of servicescape access was rarer when the virus first appeared in the country due to nationwide shortages (Porter and Ludlow, 2020).

Furthermore, although we have focused on uncovering a framework of signals that can be used by service providers across sectors, we have not established what characteristics of the signal increases its observability, nor what contextual factors determine if customers will pay attention to the signal. This is important as the interpretation of any signal is both subtle and subjective (Donath, 2007) and is often dependent on the presence of specific contextual conditions (Johnson et al., 2016). For example, Li et al. (2019) demonstrate that there is a differential effect between online and offline signals on service provider's performance in online health care. They further show that the source of a signal is important as seller signals are interpreted differently to market signals. In terms of context, an existing relationship between the service provider and customer can be an important factor influencing signal interpretation (Johnson et al., 2016).

Also, whilst a signal may be effective when it exists in isolation it may diminish in effectiveness when it operates alongside other types of signals (Bergh et al., 2014; Biswas and Biswas, 2004). This diminished effectiveness is likely to be amplified when congruent signal sets are counteracted with evidence of competing valence (Drover, 2018) within a complex servicescape. This was observed in some supermarkets during the early stages of the coronavirus. Safety signals used such as controlled access of numbers of shoppers allowed into the store, "gaffa" tape on floor and sanitiser at the entrance, were neutralized by observed customer congestion at check-outs (Scanlan, 2020). 
Further, signals are likely to erode in their contribution to a separating equilibrium "at different rates and with different trajectories (e.g., linear vs exponential)" (Bergh et al., 2014, p. 1356). For example, if too many service providers mimic a particular safety signal, its value to make inferences about safety will be reduced. The above conceptual gaps in signalling raises pertinent questions about the costs of signalling, the risks associated with signalling, the economic outcomes expected from signalling for the service provider, and the lifecycle of signals, all which provide a fruitful program of future research in the postCoronavirus era.

\section{Conclusion}

Signalling theory provides useful insights to assist service providers in their recovery efforts following the pandemic. A primary purpose of the current study was to provide a comprehensive framework of the current signals that are intentionally used by service providers to reduce customers' perceptions of physical risk of COVID-19 infection. We also open up new frontiers for future inquiry of safety signals which we believe has promise in a post pandemic world. 


\section{References}

Abbott, M.L., and McKinney, J. (2013), “Understanding and Applying Research Design”, John Wiley \& Sons, New Jersey.

Benoit, S., Scherschel, K., Ates, Z., Nasr, L. and Kandampully, J. (2017), “Showcasing the diversity of service research. Theories, methods and success of service articles", Journal of Service Management, Vol. 28 No. 5, pp. 810-836, doi.org/10.1108/JOSM-05-2017-0102

Bente, G., Baptist, O. and Leuschner H. (2012), “To buy or not to buy: Influence of seller photos and reputation on buyer trust and purchase behaviour", International Journal of Human-Computer Studies, Vol. 70 No. 1, pp. 1-13, doi.org/10.1016/j.ijhcs.2011.08.005

Bergh, D.D., Connelly, B.L., Ketchen, D. J. Jr. and Shannon, L.M. (2014), “Signalling theory and equilibrium in strategic management research: An assessment and a research agenda", Journal of Management Studies, Vol. 51 No. 8, pp. 1334-1360, doi: 10.1111/joms. 12097

Biswas, D. and Biswas, A. (2004), "The diagnostic role of signals in the context of perceived risks in online shopping: Do signals matter more on the web?" Journal of Interactive Marketing, Vol. 18 No. 3, pp. 30-45, doi.org/10.1002/dir.20010.

Bitner, M.J. (1992), “Servicescapes: The impact of physical surroundings on customers and employees", Journal of Marketing, Vol. 56, No. 2, pp. 57-71, doi: 10.2307/1252042

Bokek-Cohen, Y. (2015), "How do anonymous sperm donors signal credibility through their self-presentations?” Health Sociology Review, Vol. 24 No. 1, pp. 81-93, doi.org/10.1080/14461242.2015.1004800

Bottom, W.B., Gibson, K., Daniels, S.E. and Murnighan, J.K. (2002), "When talk is not cheap: Substantive penance and expressions of intent in rebuilding cooperation" Organization Science, Vol. 13, No. 5, pp. 497-513, doi.org/10.1287/orsc.13.5.497.7816 
Burgoon, J.K. (1993), “Interpersonal expectations, expectancy violations, and emotional communication”, Journal of Language and Social Psychology, Vol. 12, pp. 13-21, doi.org/10.1177/0261927X93121003

Calvey, M. (2020), No more cocktails or coffee: United Airlines works with Clorox, Cleveland Clinic on 'new normal', BizWomen, available at:

www.bizjournals.com/bizwomen/news/latest-news/2020/05/united-teams-up-with-clorox$\underline{\text { cleveland-clinic.html?page }=\text { all }}$ (accessed on the $10^{\text {th }}$ of June)

Chen, S. and Che, C. (2020), "Wuhan's life after lockdown isn't business as usual”, Bloomberg Businessweek. 20 April, Issue 4653, pp. 13-14.

Cohen, J. (1960), “A coefficient of agreement for nominal scales”, Educational and Psychological Measurement, Vol. 20 No 1, pp. 37-46, doi: 10.1177/001316446002000104 Collins, T. (2020), “These are the workers the U.S. government deems 'essential' amid the coronavirus pandemic", Fortune, available at: https://fortune.com/2020/03/20/essential-

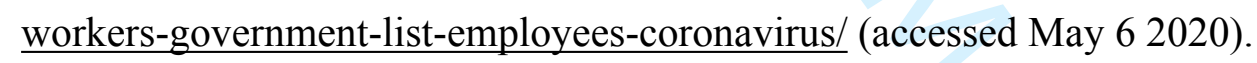

Connelly, B.L., Certo, S.T., Ireland, R.D. and Reutzel, C.R. (2011), “Signaling theory: A review and assessment”, Journal of Management, Vol. 37 No. 1, pp. 39-67, doi: $10.1177 / 0149206310388419$

Donath, J.S. (2007), “Signals in social supernets", Journal of Computer-Mediated Communication, Vol. 13, pp. 231-251, doi.org/10.1111/j.1083-6101.2007.00394.x Donath, J.S. (2011), “Signals, cues and meaning”, unpublished work, MIT Press, pp. 1-34 Drover, W., Wood, M.S. and Corbett, A.C. (2018), “Toward a cognitive view of signalling theory: Individual attention and signal set interpretation", Journal of Management Studies, Vol. 55 No. 2, pp. 209-231, doi: 10.1111/joms.12282 
Firshein, S. (2020), "The most important word in the hospitality industry? 'Clean", The New York Times, available at: https://www.nytimes.com/2020/06/03/travel/the-most-importantword-in-the-hospitality-industry-clean.html (accessed June 12 2020).

Fließ, S. and Kleinaltenkamp, M. (2004), "Blueprinting the service company managing service processes efficiently," Journal of Business Research, Vol. 57 No. 4, pp. 392-404, doi.org/10.1016/S0148-2963(02)00273-4

GOV.UK (2020), "Supermarkets to join forces to feed the nation", press release, available at: Www.gov.uk/government/news/supermarkets-to-join-forces-to-feed-the-nation (accessed May 6 2020).

Hazée, S. and Van Vaerenbergh, Y. (in press), 'Customers' contamination concerns: An integrative framework and future prospects for service management", Journal of Service Management, forthcoming.

Heinonen, K. and Strandvik, T. (in press), "Reframing service innovation: COVID-19 as catalyst for imposed service innovation", Journal of Service Management, forthcoming. Jacoby, J. and Kaplan, L.B. (1972), "The components of perceived risk", in SV - Proceedings of the Third Annual Conference of the Association for Consumer Research, eds. M. Venkatesan, Chicago, IL: Association for Consumer Research, pp. 382-393.

Johnson, J.S., Friend, S.B. and Malsh, A. (2016), "Mixed interpretations of sales proposal signals", Journal of Personal Selling \& Sales Management, Vol. 36 No. 3, pp. 264-280, doi.org/10.1080/08853134.2016.1205447

Kelleher, C., Wilson, H.N., MacDonald, E.K. and Peppard, J. (2019), “The score is not the music: Integrating experience and practice perspectives on value co-creation in collective 
consumption contexts", Journal of Service Research, Vol. 22 No. 2, pp. 120-138, doi.org/10.1177/1094670519827384

Kirmani, A. and Rao, A.R. (2000), "No Pain, no gain: A critical review of the literature on signaling unobservable product quality", Journal of Marketing, Vol. 64 No. 2, pp. 66-79, 10.1509/jmkg.64.2.66.18000

Kuppelwieser, V.G. and Finsterwalder, J. (2011), "Psychological safety, contributions and service satisfaction of customers in group service experiences", Managing Service Quality, Vol. 21 No. 6, pp. 617-635, doi 10.1108/09604521111185619

Li, J., Tang, J., Jiang, L., Yen, D.C. and Liu, X. (2019), “Economic success of physicians in the online consultation market: A signalling theory perspective", International Journal of Electronic Commerce, Vol. 23 No. 2, pp. 244-271, doi.org/10.1080/10864415.2018.1564552 Li, H., Fang, Y., Wang, Y., Lim, K.H., and Liang, L. (2015), "Are all signals equal? Investigating the differential effects of online signals on the sales performance of emarketplace sellers", Information Technology \& People, Vol. 28 No. 3, pp. 699-723, doi.org/10.1108/ITP-11-2014-0265

Love, P.E.D., Teo, P., Carey, B., Sing, C-P., and Ackermann, F. (2015), “The symbiotic nature of safety and quality in construction: Incidents and rework non-conformances", Safety Science, Vol. 79 November, pp. 55-62, doi.org/10.1016/j.ssci.2015.05.009 Mavlanova, T., Benbunan-Fich, R. and Koufaris, M. (2012), "Signaling theory and information asymmetry in online commerce", Information \& Management, Vol. 49, pp. 240247, doi.org/10.1016/j.im.2012.05.004 
Moeller, S. (2008), “Customer integration - A key to an implementation perspective of service provision”, Journal of Service Research, Vol. 11 No. 2, pp. 197-210, doi.org/10.1177/1094670508324677

Porter, Jr.G. and Ludlow, E. (2020), "Hand sanitizer will be hard to find for a long time", Bloomberg available at: https://www.bloomberg.com/news/articles/2020-04-08/handsanitizer-is-going-to-be-hard-to-find-for-a-long-long-time (accessed June 10 2020).

Rao, A.R., Rao, L. and Rueckert, R.W. (1999), “Signaling unobservable product quality through a brand ally" Journal of Marketing Research, Vol. 36 No. 2, pp. 258-268, doi: $10.2307 / 3152097$

Rosenbaum, M.S. and Massiah, C. (2011), “An expanded servicescape perspective”, Journal of Service Management, Vol. 22 No. 4, pp. 471-490, doi 10.1108/09564231111155088

Scanlan, R. (2020), “Supermarket shoppers furious at 'packed' aisles”, Daily Mercury, available at: https://www.dailymercury.com.au/news/disgraceful-supermarket-aislespacked/3993563/ (accessed June 10 2020).

Spence, M. (1974), “Competitive and optimal responses to signals: An analysis of efficiency and distribution", Journal of Economic Theory, Vol. 7 No. 3, pp. 296-332, doi.org/10.1016/0022-0531(74)90098-2

Tuzovic, S. and Kabadayi, S. (in press), "The influence of social distancing on employee wellbeing: A conceptual framework and research agenda”, Journal of Service Management, forthcoming.

Tyko, K. (2020), “Preventing coronavirus spread: Walmart, Kroger, Albertsons among grocers adding sneeze guards", USA TODAY, available at: 
https://www.desertsun.com/story/money/2020/03/24/walmart-kroger-albertsons-coronavirusresponse-sneeze-guards/2913538001/ (accessed May 6 2020).

WHO (2020), available at: https://www.who.int/news-room/commentaries/detail/immunitypassports-in-the-context-of-covid-19 (accessed May 3 2020).

Wittel, L., Holmlund, M. and Gustafsson, A. (2020), “Guest editorial: A new dawn for qualitative service research", Journal of Services Marketing, Vol. 34 No. 1, pp. 1-7, doi.org/10.1108/JSM-11-2019-0443

Yen, H.J.R. (2006), "Risk-reducing signals for new online retailers: a study of single and multiple signalling effects", International Journal of Internet Marketing and Advertising, Vol. 3, No. 4, pp.299-317, doi: 10.1504/IJIMA.2006.012685 


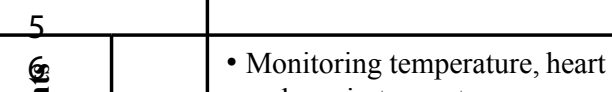

and respiratory rate

- Booking platforms for walk-ins

- Curtailed shopping hours to

allow extra cleaning

Servicescape

Communication

Physical environment

Tangibles

若

- Contactless check-in

- Restriction on the number of

customers, e.g. one in, one out

policies

- Designated shopping hours for

key workers and vulnerable

customers

- Commencing or reducing service

portfolio to delivery

- Restrict customers access

depending on protection level

- Changing the way customers

access the service, e.g. middle

door of busses

- Delivery fee waiver for

vulnerable customers

- Extending opening hours

- Social distancing floor

- Replacement of multi-use

stickers

boxes with disposable

packaging of deliveries

- Virus repellent fabrics

cleaning

- Increased cleaning of items

- Provision of accessible

handwashing facilities

and/or hand sanitizer

customers touch

- Rollout of contactless payment

- Design to minimize

and check-in facilities

contact with surfaces

e.g., hands-free door

- Protective shields around high-

- Tamper evident seals for

deliveries

- Contactless digital menu

- One-way isles to

manage traffic flow

- Removal of all

furniture to avoid

congregations
- "Touch it, take it" policies

- Advice to customers to wash

and self-handle reusable bags

- Customer advice to self-swipe

card on payment

- Suspension of product

sampling

Staff

contact staff

- Regular testing, temperature

and traceability checks

- Provision of protective

equipment for staff e.g., gloves

and masks

- Introduction of virus detection

dogs

- Introduction of "germ-

zapping" robots

- Staff hygiene auditing

- Sanitize delivery staff
- Monitoring

temperature, heart

and respiratory rate

- Provision of

protective equipment

for customers e.g.,

gloves
Other customers

about servicescape

- Use of language

signaling safety

customers

- Provision of health \& safety kits

- Removal of non-essential,

courtesy staff

- Leave at my door delivery

- Online only, no-counter

ordering

- Advice not to bring

extra people into

stores

- Change in communal

sharing practices

announcements for

social distancing

- Best time to come

indication
- Suspension customer items

entering the servicescape

- Suspension of reusable

programs

- Removal of items used in the service process, e.g., baskets, trays or magazines
- Staff increased hand washing

routines

- Compensation to staff

including peer service

providers with positive

diagnosis 
Web Appendix 1: Examples of service provider safety signals

\begin{tabular}{|c|c|}
\hline \multicolumn{2}{|c|}{ Access: default and sales independent signals } \\
\hline $\begin{array}{l}\text { Monitoring temperature, heart and } \\
\text { respiratory rate }\end{array}$ & $\begin{array}{l}\text { Airlines such as Etihad Airways and Emirates have implemented means, e.g., contactless self-service devices or kiosks to } \\
\text { monitor customer temperature, heart rate and respiratory rate (see Etihad 2020; McNutt, 2020) }\end{array}$ \\
\hline Booking platform for walk-in shops & $\begin{array}{l}\text { Use of booking platform for reserving shopping times in supermarkets or retail stores (e.g., OpenTable } \\
\text { https://www.opentable.com/ a restaurant reservation platform has expanded its service to let users to reserve timeslots for } \\
\text { shopping at participating grocery and retail stores in the US) }\end{array}$ \\
\hline $\begin{array}{l}\text { Curtail shopping hours to allow } \\
\text { extra cleaning }\end{array}$ & $\begin{array}{l}\text { Walmart curtailed shopping hours in some of their stores with } 24 \mathrm{~h} \text { opening to allow time for extra cleaning (Redman, } \\
\text { 2020a) }\end{array}$ \\
\hline \multicolumn{2}{|c|}{ Access: default independent signals, but sales contingent } \\
\hline $\begin{array}{l}\text { Introduction of revised cleaning } \\
\text { protocols }\end{array}$ & $\begin{array}{l}\text { Airbnb have launched an Enhanced Cleaning Initiative, a new cleaning protocol for hosts to secure future bookings that } \\
\text { gives reassurance to guests https://www.airbnb.com.au/resources/hosting-homes/g/exploring-the-enhanced-cleaning_- } \\
\text { protocol-8 }\end{array}$ \\
\hline Contactless check-in & $\begin{array}{l}\text { Diners can scan a QR code placed at the restaurant entrance to self-check in, reducing any non-essential interaction with } \\
\text { staff. (Inresto Blog, 2020) }\end{array}$ \\
\hline \multicolumn{2}{|c|}{ Access: default contingent signals, revenue risking } \\
\hline $\begin{array}{l}\text { Restriction on the number of } \\
\text { customers }\end{array}$ & $\begin{array}{l}\text { Various retailers in the UK have limited the access and implemented designated waiting areas outside and a one in, one out } \\
\text { policies (e.g., Redman, 2020e; } 2020 \mathrm{f} \text {; Walsh, 2020), use of digital waiting rooms for medical clinics (e.g., LineTweet } \\
\text { https://www.linetweet.com/live where patients call the reception from their home, get a personal waiting number and a link } \\
\text { via SMS to check the waiting status online and can then enter the medical practice when their turn comes.) } \\
\text { Hotels have restricted the number of people in elevators to e.g. } 2 \text { or } 4 \text { people (Hunter, 2020) }\end{array}$ \\
\hline $\begin{array}{l}\text { Special shopping hours for key } \\
\text { workers and vulnerable people }\end{array}$ & $\begin{array}{l}\text { Various retailers in the UK e.g., Asda or Sainsbury, provided special hours for healthcare workers and/or for vulnerable } \\
\text { consumers such as elderly (Sayce, 2020) }\end{array}$ \\
\hline $\begin{array}{l}\text { Commencing or reducing service } \\
\text { portfolio to delivery }\end{array}$ & $\begin{array}{l}\text { Restaurants move from dine-in only to delivery, takeout and curbside pickup (e.g., Dunkin Donuts } \\
\text { https://news.dunkindonuts.com/blog/dunkin-preventative-measures-coronavirus; Dawson, 2020) }\end{array}$ \\
\hline $\begin{array}{l}\text { Restrict customers access } \\
\text { depending on protection level }\end{array}$ & Airlines, such as Emirates and grocery stores, such as Aldi demand customers to wear masks and gloves (McNutt, 2020) \\
\hline \multicolumn{2}{|c|}{ Access: default contingent signals, cost risking } \\
\hline $\begin{array}{l}\text { Changing the way customers access } \\
\text { the servicescape }\end{array}$ & $\begin{array}{l}\text { Transport for London has restricted access to middle doors of busses so that passengers do not have to pass by the driver } \\
\text { (e.g., https://tfl.gov.uk/info-for/media/press-releases/2020/april/tfl-trials-safer-boarding-on-london-s-buses) or hotels have a } \\
\text { single point of entry to check temperature (Hunter, 2020) }\end{array}$ \\
\hline $\begin{array}{l}\text { Delivery fee waiver for vulnerable } \\
\text { customers }\end{array}$ & Various US foodservice providers e.g., Piggly Wiggly waive the delivery fee for vulnerable customers (Redman 2020c) \\
\hline
\end{tabular}




\begin{tabular}{|c|c|}
\hline Extending opening hours & Sainsbury extended opening hours in order to reduce queuing outside and inside the store (Devlin, 2020) \\
\hline \multicolumn{2}{|c|}{ Physical Environment: default and sales independent signals } \\
\hline Social distancing floor stickers & Implemented in stores, airports and other service locations (McNutt, 2020; Redman 2020h) \\
\hline Increased level of cleaning & $\begin{array}{l}\text { Various airlines, hotel groups and stores around the world (Business Traveller, 2020; Redman, 2020a; Hunter, 2020; } \\
\text { McNutt, 2020) }\end{array}$ \\
\hline Provision of handwashing facilities & $\begin{array}{l}\text { Provision of accessible handwashing facilities and/or hand sanitizers for staff and customers (e.g., Lush who invite the } \\
\text { public to wash their hands in-store; Petter, 2020) }\end{array}$ \\
\hline $\begin{array}{l}\text { Design to minimize contact with } \\
\text { surfaces e.g., hands-free door }\end{array}$ & $\begin{array}{l}\text { Design to minimize contact (e.g., Finnish Fortum Vipu, a hands-free door handle that allows customers to open doors and } \\
\text { cabinets with forearm, https://www.fortum.com/vipu/) }\end{array}$ \\
\hline \multicolumn{2}{|c|}{ Physical Environment: default independent signals, but sales contingent } \\
\hline-- & 20 \\
\hline \multicolumn{2}{|c|}{ Physical Environment: default contingent signals, revenue risking } \\
\hline $\begin{array}{l}\text { One-way isles to manage traffic } \\
\text { flow }\end{array}$ & $\begin{array}{l}\text { Walmart, Kroger or Aldi have implementation one-way isles to manage customer and personnel flow and allow for social } \\
\text { distancing (Redman, 2020f; Redman, 2020h) }\end{array}$ \\
\hline $\begin{array}{l}\text { Removal of all furniture to avoid } \\
\text { congregations }\end{array}$ & $\begin{array}{l}\text { Marriott or Dunkin Donuts removed furniture in their public spaces to avoid congregation of customers in store and to } \\
\text { encourage social distancing (Dawson, 2020; Hunter, 2020) }\end{array}$ \\
\hline \multicolumn{2}{|c|}{ Physical Environment: default contingent signals, cost risking } \\
\hline-- & 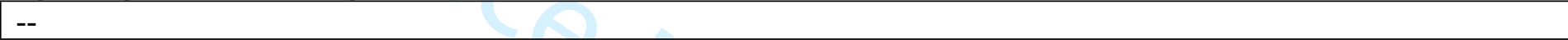 \\
\hline \multicolumn{2}{|c|}{ Tangibles: default independent signals, sales independent } \\
\hline $\begin{array}{l}\text { Replacing multi-use boxes with } \\
\text { disposable packaging of deliveries }\end{array}$ & $\begin{array}{l}\text { Tesco replaced their multi-use boxes with disposable packaging that is left in front of the house so that delivery drivers do } \\
\text { not have to interact with the customer or enter the house (Farrow, 2020) }\end{array}$ \\
\hline Virus repellent fabrics & Bedding, towels or uniforms are made from anti-pathogen fabric (e.g., Sonovia http://sonoviatech.com/) \\
\hline $\begin{array}{l}\text { Increased cleaning of items } \\
\text { customers touch }\end{array}$ & $\begin{array}{l}\text { Increased cleaning of shopping carts by Walmart of Kroger (Business Traveller, 2020; Hunter, 2020; Redman 2020a; } \\
2020 \mathrm{~g} \text { ) }\end{array}$ \\
\hline $\begin{array}{l}\text { Extension or rollout of contactless } \\
\text { payment and check-in facilities }\end{array}$ & $\begin{array}{l}\text { Most UK retailers have lifted the threshold for contactless payment from } £ 30 \text { to } £ 45 \text { (Baldwin, 2020; Walsh, 2020), Tesco, } \\
\text { Waitrose and Publix rolled out contactless payment facilities in all of its } 1,200 \text { stores (Redman 2020d, Walsh 2020). Hotels } \\
\text { introduce contactless keys and check-in (Hunter, 2020) }\end{array}$ \\
\hline-- & 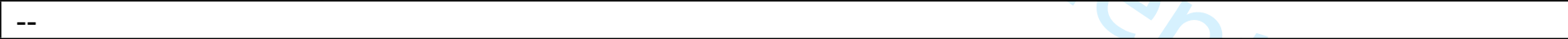 \\
\hline \multicolumn{2}{|c|}{ Tangibles: default independent signals, but sales contingent } \\
\hline Tamper evident seals for deliveries & $\begin{array}{l}\text { KFC has implemented tamper-evident seals for their food deliveries to ensure no-one has touched the food after it has left } \\
\text { the store (Ruggless, 2020) }\end{array}$ \\
\hline Contactless digital menu & Diners can place an order by scanning a QR code, eliminating the need to handle paper menus (Inresto Blog, 2020) \\
\hline
\end{tabular}




\begin{tabular}{|c|c|}
\hline "Touch it, take it" policies & Aldi and Asda ask customers to only touch what they intend to buy (Walsh 2020) \\
\hline $\begin{array}{l}\text { Advice to customers to wash and } \\
\text { self-handle reusable bags }\end{array}$ & Advice to customers to wash/disinfect and self-handle their re-usable bags (Redman, 2020g) \\
\hline $\begin{array}{l}\text { Customer advice to self-swipe card } \\
\text { on payment }\end{array}$ & Chick-fil-A instructed their staff to ask customers to swipe their own bank cards on payment (Luna, 2020) \\
\hline Suspension of product sampling & Publix suspended all product and recipe sampling in store (Redman, 2020d) \\
\hline $\begin{array}{l}\text { Behind the counter placement of } \\
\text { non-single use condiments }\end{array}$ & Publix placed non-single used condiments such as creamer or squeeze bottles behind the counter (Redman 2020d) \\
\hline \multicolumn{2}{|c|}{ Tangibles: default contingent signals, cost risking } \\
\hline $\begin{array}{l}\text { Suspension of customer items } \\
\text { entering the servicescape }\end{array}$ & Airlines suspend allowing customers to bring carry-on bags into the aircraft (McNutt, 2020) \\
\hline Suspension of reusable programs & $\begin{array}{l}\text { Many retailers such as Hy-Vee or Ocado ban reusable bags from customers (Redman, 2020b). Restaurants such as } \\
\text { JustSalad, Starbucks or Dunkin have discontinued reusable programs, in which customers use their own cup or bowl } \\
\text { (Fantozzi, 2020) }\end{array}$ \\
\hline $\begin{array}{l}\text { Removal of items used in service } \\
\text { process e.g., baskets, trays, } \\
\text { magazine, table decor }\end{array}$ & $\begin{array}{l}\text { Subway has removed dine-in sandwich baskets and serving trays (Fantozzi, 2020). Emirates has removed the magazines } \\
\text { from airplanes (McNutt, 2020) }\end{array}$ \\
\hline \multicolumn{2}{|c|}{ Staff: default and sales independent signals } \\
\hline $\begin{array}{l}\text { Protective shields around high- } \\
\text { contact staff }\end{array}$ & $\begin{array}{l}\text { Hotels and grocery chains instal transparent shields around high-contact staff e.g., cashiers, to protect staff and customers } \\
\text { (Hunter, 2020; Redman, 2020h) }\end{array}$ \\
\hline $\begin{array}{l}\text { Regular testing, temperature and } \\
\text { traceability checks }\end{array}$ & $\begin{array}{l}\text { Amazon wants to regularly test its workers (https://www.pymnts.com/news/retail/2020/amazon-ceo-bezos-seeks-covid-19- } \\
\text { testing-for-staff/). Walk-in booths for employee temperature and traceability checks (e.g., Damstra digital workplace } \\
\text { management https://www.damstratechnology.com/and Redman, 2020h) }\end{array}$ \\
\hline $\begin{array}{l}\text { Provision of protective equipment } \\
\text { for staff e.g., gloves and masks }\end{array}$ & Various grocery chains (e.g., Kroger or Walmart) provide hand sanitizer or face masks to their staff (Redman 2020a). \\
\hline $\begin{array}{l}\text { Introduction of Covid-19 detection } \\
\text { dogs }\end{array}$ & $\begin{array}{l}\text { The presence of COVID-19 detection dogs (e.g., Canines, the medical detection dog charity who are training dogs to detect } \\
\text { infected passengers at airports https://news.sky.com/story/coronavirus-dogs-being-trained-to-find-passengers-with-covid- } \\
\text { 19-at-airports-11976965) }\end{array}$ \\
\hline $\begin{array}{l}\text { Introduction of "germ-zapping" } \\
\text { robots }\end{array}$ & $\begin{array}{l}\begin{array}{l}\text { LightStrike "Germ-Zapping" Robots are offered by Xenex disinfection services https://www.xenex.com/our- } \\
\text { solution/lightstrike/ }\end{array}\end{array}$ \\
\hline Staff hygiene auditing & $\begin{array}{l}\text { Accor and Hilton hotels have adopted iAuditor from Safety Culture which is a customised checklist app that prompts staff } \\
\text { with frequent and simple tasks that must be completed to ensure safety requirements continue to be met (Hotel } \\
\text { Management, 2020) }\end{array}$ \\
\hline
\end{tabular}




\begin{tabular}{|c|c|}
\hline Sanitize delivery staff & $\begin{array}{l}\text { Haidilao Restaurant Chain in China sprays delivery staff with medical alcohol before getting them to step into disinfectant } \\
\text { to sterilize the soles of their shoes https://mustsharenews.com/china-haidilao-disinfection/ }\end{array}$ \\
\hline \multicolumn{2}{|c|}{ Staff: default contingent signals, revenue risking } \\
\hline $\begin{array}{l}\text { Removal of non-essential courtesy } \\
\text { staff }\end{array}$ & $\begin{array}{l}\text { Hotels and Airlines (e.g., Emirates) are preparing to cut back on personal interactions between staff and customers, e.g. } \\
\text { valet services or greeters leaving the aircraft (Hunter, 2020; McNutt, 2020) }\end{array}$ \\
\hline Leave at my door delivery option & Postmates or Door Dash implemented delivery without the need to directly interact with delivery staff (Luna, 2020) \\
\hline Online only, no-counter ordering & Noodles a US restaurant chain has suspended ordering at the counter in favor of online ordering (Luna, 2020) \\
\hline \multicolumn{2}{|c|}{ Staff: default contingent signals, cost risking } \\
\hline $\begin{array}{l}\text { Staff increased hand washing } \\
\text { routines }\end{array}$ & Chick-fil-A instruct their staff to wash hands every 30 minutes and every time they have handled cash (Luna, 2020) \\
\hline $\begin{array}{l}\text { Compensation of peer service } \\
\text { providers with positive diagnosis }\end{array}$ & $\begin{array}{l}\text { To reduce the risk of infected drivers continuing to work, Uber compensates drivers who show "proper documentation" of } \\
\text { being diagnosed or having to self-isolate due to the virus and then removes them from the app for } 14 \text { days (Luna, 2020) }\end{array}$ \\
\hline \multicolumn{2}{|c|}{ Other customers: default and sales independent signals } \\
\hline $\begin{array}{l}\text { Monitoring temperature, heart and } \\
\text { respiratory rate }\end{array}$ & $\begin{array}{l}\text { Contactless self-service devices to monitor customer temperature, heart rate and respiratory rate (Etihad 2020, Hunter, 2020; } \\
\text { Siret, 2020) }\end{array}$ \\
\hline $\begin{array}{l}\text { Provision of protective equipment, } \\
\text { e.g., gloves and masks }\end{array}$ & $\begin{array}{l}\text { Various hotels, airlines and grocery chains provide hand sanitizer or wipes to customers (Business Traveller, 2020; Luna, } \\
\text { 2020; Redman, 2020a; Siret, 2020) }\end{array}$ \\
\hline \multicolumn{2}{|c|}{ Other customers: default independent signals, but sales contingent } \\
\hline Protective shields for customers & $\begin{array}{l}\text { Meituan, a major food delivery platform in China provides customers with a disposable shield to protect themselves from } \\
\text { other diners when eating noodles in office canteens }(\mathrm{Hu}, 2020) \text { or Publix installing protective shields for customers on } \\
\text { checkouts (Redman, 2020d) }\end{array}$ \\
\hline $\begin{array}{l}\text { Provide health \& safety kits to } \\
\text { customers }\end{array}$ & $\begin{array}{l}\text { Instacart distribute free health and safety kits (including face mask, sanitizer or thermometers) to the online grocer's full- } \\
\text { service shoppers (Browne, 2020) }\end{array}$ \\
\hline \multicolumn{2}{|c|}{ Other customers: default contingent signals, revenue risking } \\
\hline $\begin{array}{l}\text { Advice not to bring extra people } \\
\text { into stores }\end{array}$ & Hy-Vee encourage a "one-person per cart" rule to discourage family shopping together (Redman, 2020b) \\
\hline $\begin{array}{l}\text { Change in communal sharing } \\
\text { practices }\end{array}$ & Removal of communal dishes and buffets designed for sharing in restaurants (Dandan, 2020) \\
\hline \multicolumn{2}{|c|}{ Other customers: default contingent signals, cost risking } \\
\hline-- & 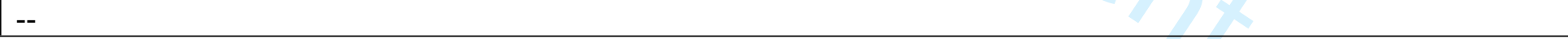 \\
\hline \multicolumn{2}{|c|}{ Communication: default and sales independent signals } \\
\hline Use of language signaling safety & $\begin{array}{l}\text { Use of words signaling safety in marketing communications (e.g., DiDi Hero, https://didiaustralia.blog/didi-hero/ a } \\
\text { dedicated ride service for healthcare workers, uses words such as "safer, highly sanitized, disinfecting" in its launch in } \\
\text { Melbourne, Australia) }\end{array}$ \\
\hline
\end{tabular}




\begin{tabular}{|c|c|}
\hline \multicolumn{2}{|c|}{ Communication: default independent signals, but sales contingent } \\
\hline-- & - \\
\hline \multicolumn{2}{|c|}{ Communication: default contingent signals, revenue risking } \\
\hline $\begin{array}{l}\text { In-store announcements for social } \\
\text { distancing }\end{array}$ & $\begin{array}{l}\text { Kroger or Aldi keep reminding people to remain socially distanced through frequent in-store announcements (Redman, } \\
\text { 2020f; Redman, 2020h) }\end{array}$ \\
\hline Best time to come indication & $\begin{array}{l}\text { Color coded indicator via app available online to indicate when the store is busiest (red) to least busy (green) to allow for } \\
\text { social distancing (Grant, 2020) }\end{array}$ \\
\hline \multicolumn{2}{|c|}{ Communication: default contingent signals, cost risking } \\
\hline-- & -- \\
\hline
\end{tabular}

\section{References:}

Baldwin, C. (2020), “Covid-19: Contactless limit raised from $£ 30$ to $£ 45 ”$, available at: www.essentialretail.com/news/covid19-contactless-limit-45/ (accessed $1^{\text {st }}$ of May).

Brown, M. (2020), "Instacart to distribute health and safety kits to its shopper community”, Supermarket News, $2^{\text {nd }}$ of April 2020

Business Traveller (2020), "Hotels ramp up cleaning measures amid coronavirus pandemic”, available at: https://www.businesstraveller.com/features/hotelsramp-up-cleaning-measures-amid-coronavirus-pandemic/ (accessed $1^{\text {st }}$ of May).

Dandan, M. (2020), "No more sharing of communal dishes: A revolution of Chinese dining habits?”, available at: https://www.thinkchina.sg/no-moresharing-communal-dishes-revolution-chinese-dining-habits (accessed $1^{\text {st }}$ of May)

Dawson, G. (2020), “Dunkin' moves to limited service and removes tables and chairs from its over 8,500 stores in the U.S.”, Nation's Restaurant News, $17^{\text {th }}$ of March 2020

Devlin, E. (2020), “Sainsbury's to extend opening hours and reopen petrol station stores”, The Grocer, $23^{\text {rd }}$ of April 2020.

Ethihad (2020), "Etihad Airways to test airport technology to help identify medically at-risk travellers", available at: https://www.etihad.com/enau/news/etihad-airways-to-test-airport-technology-to-help-identify-medically-at-risk-travellers (accessed 23 $3^{\text {rd }}$ of April 2020). 
Fantozzi, J. (2020), "Reusables movement hits speed bump during coronavirus pandemic", Nation's Restaurant News, $13^{\text {th }}$ of March 2020

Farrow, C. (2020), “Tesco makes changes to online delivery service in light of coronavirus - what you need to know”, available at: www.shieldsgazette.com/health/tesco-makes-changes-online-delivery-service-light-coronavirus-what-you-need-know-2450767 (accessed $22^{\text {nd }}$ of April 2020).

Fortum Vipu (2020), “An infection-preventing hands-free handle - made from Fortum Circo ${ }^{\circledR}$ recycled plastic”, available at:

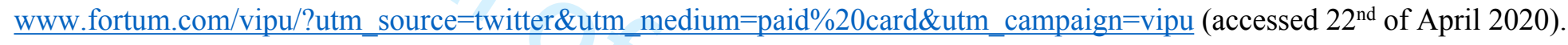

GOV.UK (2020), “TfL trials safer boarding on London's buses”, available at: https://ffl.gov.uk/info-for/media/press-releases/2020/april/tfl-trials-saferboarding-on-london-s-buses (accessed 22 $2^{\text {nd }}$ of April 2020).

Grant, K. (2020), “Coronavirus: Supermarket 'check-in' app shows shoppers quietest time to visit stores and stock availability during UK lockdown”, available at: https://inews.co.uk/news/consumer/oronavirus-supermarket-check-in-app-when-visit-stores-stock-uk-lockdown-2546628 (accessed $25^{\text {th }}$ of April).

Hotel Management (2020), "SafetyCulture is your ticket to a safer guest environment", available at: www.hotelmanagement.com.au/sponsoredcontent/safetyculture-is-your-ticket-to-a-safer-guest-environment/ (accessed $1^{\text {st }}$ May 2020).

Hu, M. (2020), "Meituan Dianping offers 'contactless shields' that allow people to eat their delivered food in private", available at: www.scmp.com/tech/apps-social/article/3074644/meituan-dianping-offers-contactless-shields-allow-people-eat-their (accessed 19 ${ }^{\text {th }}$ of April 2020).

Hunter, M. (2020), "What will staying in a hotel look like in the near future?" CNN travel, available at: https://edition.cnn.com/travel/article/hotels-safetycoronavirus/index.html (accessed $7^{\text {th }}$ of May 2020). 
Inresto Blog (2020), "Reinventing the wheel: Dining out in the post-COVID era", available at: https://inresto.com/blog/2020/05/04/reinventing-the-wheeldining-out-in-the-post-covid-era-2/ (accessed $1^{\text {st }}$ of May).

Luna, N. (2020), "Chick-fil-A to add handwashing stations at drive-thru restaurants", Nation's Restaurant News, $6^{\text {th }}$ of April 2020

Lush (2020), "Hand Washing: A How-To", available at: https://au.lush.com/article/hand-washing-how (accessed 24th of April 2020).

McNutty, E. (2020), "Emirates says no carry-on bags allowed on board, all passengers must wear mask and gloves”, available at: https://thepointsguy.co.uk/news/emirates-coronavirus-ppe-measures/(accessed 24th of April 2020).

Petter, O. (2020), "Coronavirus: Lush invites people into its shops to wash their hands to prevent spread", Independent, available at: www.independent.co.uk/life-style/health-and-families/coronavirus-news-lush-hand-washing-free-spread-uk-a9369101.html, (accessed 1 ${ }^{\text {st }}$ May, 2020).

Redman, R. (2020a), “Coronavirus: How leading grocery chains are responding to keep customers safe and shelves stocked”, Supermarket News, $13^{\text {th }}$ of March 2020.

Redman, R. (2020b), "Hy-Vee bans reusable bags, adds safety windows at checkout”, Supermarket News, $20^{\text {th }}$ of March 2020

Redman, R. (2020c), “Grocery retailers waive DoorDash delivery fees for older customers”, Supermarket News, $27^{\text {th }}$ of March 2020

Redman, R. (2020d), "Publix deploys contactless payment for extra COVID-19 safety", Supermarket News, $3^{\text {rd }}$ of April 2020

Redman, R. (2020e), “Target to meter shopper traffic as coronavirus safety measure”, Supermarket News, $3^{\text {rd }}$ of April 2020

Redman, R. (2020f) "UPDATE: Walmart, Kroger, Hy-Vee, Giant go with one-way aisles to combat coronavirus", Supermarket News, 6th of April 2020

Redman, R. (2020g), “California Grocers Association lists top 10 safe shopping tips”, Supermarket News, $8^{\text {th }}$ of April 2020

Redman, R. (2020h), “Discount grocers Aldi, Lidl institute customer limits in stores”, Supermarket News, $10^{\text {th }}$ of April 2020

Ruggless, R. (2020), “KFC closes dining rooms amid coronavirus pandemic”, Nation's Restaurant News, $18^{\text {th }}$ of March 2020 
Sayce, Rebecca (2020), "When your local supermarket is open for elderly, vulnerable, NHS and care staff”, available at:

www.expressandstar.com/news/business/2020/03/23/when-your-local-supermarket-is-open-for-elderly-vulnerable-nhs-and-care-staff/, (accessed $7^{\text {th }}$ of May 2020).

Siret, M. (2020), “Coronavirus: What global travel may look like ahead of a vaccine”, available at: www.bbc.co.uk/news/world-52450038, (accessed $7^{\text {th }}$ of May 2020).

Walsh, H. (2020), “Coronavirus supermarkets latest: are shopping habits getting back to normal?”, available at: www.which.co.uk/news/2020/05/supermarkets-coronavirus-latest/, (accessed $7^{\text {th }}$ of May 2020). 


\section{Web Appendix 2: Typology of marketing seller quality signals}

\begin{tabular}{|c|c|c|c|}
\hline \multicolumn{2}{|c|}{$\begin{array}{l}\text { Kirmani and Rao (2000) } \\
\text { Typology of Marketing } \\
\text { Signals }\end{array}$} & $\begin{array}{l}\text { The nature or type of signal } \\
\text { communicated to reduce } \\
\text { performance risk }\end{array}$ & Authors \\
\hline \multirow[t]{17}{*}{$\begin{array}{l}\text { Default- } \\
\text { independent } \\
\text { signals }\end{array}$} & \multirow[t]{17}{*}{$\begin{array}{l}\text { Sale- } \\
\text { Independent }\end{array}$} & $\begin{array}{l}\text { Investment in brand-related } \\
\text { advertising }\end{array}$ & $\begin{array}{l}\text { Aiken and Boush, 2006; Biswas and } \\
\text { Biswas, 2004; Kirmani and Rao, } \\
2000 .\end{array}$ \\
\hline & & $\begin{array}{l}\text { Investment in brand } \\
\text { name/reputation }\end{array}$ & $\begin{array}{l}\text { Biswas and Biswas, 2004; Kirmani } \\
\text { and Rao, 2000; Kozlenkova et al., } \\
\text { 2017; Lee et al., 2005; Li et al., } \\
\text { 2015; Li et al., 2019. }\end{array}$ \\
\hline & & $\begin{array}{l}\text { Third part endorsement, } \\
\text { certification, seals or prestigious } \\
\text { affiliates }\end{array}$ & $\begin{array}{l}\text { Aiken and Boush, 2006; Ballina, } \\
\text { Valdés and Del Valle, 2020; Li et } \\
\text { al., 2009; Mavlanova et al. 2012; } \\
\text { Pollock et al., 2010; Yen, } 2006\end{array}$ \\
\hline & & $\begin{array}{l}\text { Use of a credible intermediary } \\
\text { e.g., retailer }\end{array}$ & $\begin{array}{l}\text { Kirmani and Rao, 2000; Li et al., } \\
\text { 2009; Pollock et al., 2004. }\end{array}$ \\
\hline & & $\begin{array}{l}\text { Seller photos or pictures of } \\
\text { products }\end{array}$ & $\begin{array}{l}\text { Bente, Baptist, and Leuschner, } \\
\text { 2012; Bokek-Cohen, 2015; Li et al., } \\
\text { 2009. }\end{array}$ \\
\hline & & $\begin{array}{l}\text { Seller profile descriptions, } \\
\text { narratives, press releases, FAQ } \\
\text { sections and news }\end{array}$ & $\begin{array}{l}\text { Bokek-Cohen, 2015; Mavlanova et } \\
\text { al., } 2012\end{array}$ \\
\hline & & Seller knowledge contribution & Li et al., 2019 \\
\hline & & $\begin{array}{l}\text { Presence of privacy policy on } \\
\text { seller's website }\end{array}$ & $\begin{array}{l}\text { Lee et al., 2005; Mavlanova et al., } \\
2012\end{array}$ \\
\hline & & $\begin{array}{l}\text { Seller's information peacocking } \\
\text { and/or relationship peacocking }\end{array}$ & Chase and Murtha, 2019 \\
\hline & & $\begin{array}{l}\text { Seller embedding its specific } \\
\text { capabilities and/or language in } \\
\text { sales proposal }\end{array}$ & Chase and Murtha, 2019 \\
\hline & & $\begin{array}{l}\text { Sales proposal specificity or } \\
\text { explicit responding in sales } \\
\text { proposal }\end{array}$ & $\begin{array}{l}\text { Chase and Murtha, 2019; Johnson } \\
\text { et al., } 2016\end{array}$ \\
\hline & & $\begin{array}{l}\text { Seller reference matching, } \\
\text { positively toned responding } \\
\text { and/or tailored responding in } \\
\text { sales proposal }\end{array}$ & Chase and Murtha, 2019 \\
\hline & & $\begin{array}{l}\text { Seller offering novel solutions } \\
\text { and/or supplemental solutions in } \\
\text { sales proposal }\end{array}$ & Chase and Murtha, 2019 \\
\hline & & $\begin{array}{l}\text { Website quality i.e., visual } \\
\text { appeal, data quality, and } \\
\text { security. }\end{array}$ & Li et al., 2015; \\
\hline & & Website live chat & Mavlanova et al., 2012 \\
\hline & & The presence of physical stores & Yen, 2006; Mavlanova et al., 2012 \\
\hline & & $\begin{array}{l}\text { Seller geographic location, } \\
\text { website contact information }\end{array}$ & $\begin{array}{l}\text { Lanzolla and Frankort, 2016; } \\
\text { Mavlanova et al., 2012 }\end{array}$ \\
\hline
\end{tabular}




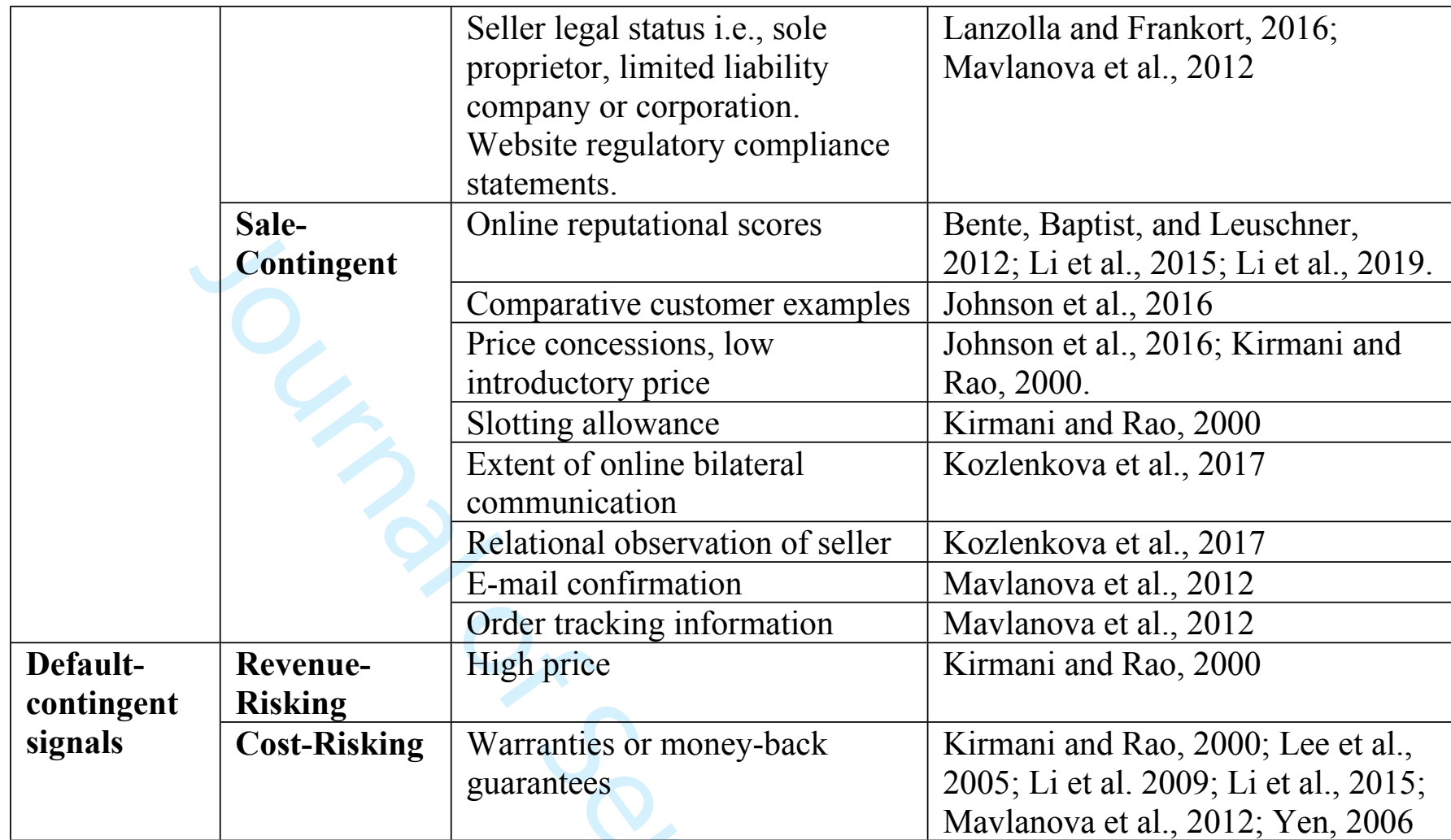




\section{References:}

Aiken, K.D. and Boush, D.M. (2006), “Trustmarks, objective-source ratings, and implied investments in advertising: Investigating online trust and the context-specific nature of internet signals", Journal of the Academy of Marketing Science, Vol. 34 No. 3, pp. 308-323, doi.org/10.1177/0092070304271004

Ballina, F.J., Valdés, L. and Del Valle, E. (2020), “The signalling theory: The key role of quality standards in the hotels performance", Journal of Quality Assurance in Hospitality \& Tourism, Vol. 21 No. 2, pp. 190-208, doi.org/10.1080/1528008X.2019.1633722

Bente, G., Baptist, O. and Leuschner, H. (2012), "To buy or not to buy: Influence of seller photos and reputation on buyer trust and purchase behaviour", International Journal of Human-Computer Studies, Vol. 70 No. 1, pp. 1-13, doi.org/10.1016/j.ijhcs.2011.08.005 Biswas, D. and Biswas, A. (2004), "The diagnostic role of signals in the context of perceived risks in online shopping: Do signals matter more on the web?" Journal of Interactive Marketing, Vol. 18 No. 3, pp. 30-45, doi.org/10.1002/dir.20010.

Bokek-Cohen, Y. (2015), "How do anonymous sperm donors signal credibility through their self-presentations?” Health Sociology Review, Vol. 24 No. 1, pp. 81-93, doi.org/10.1080/14461242.2015.1004800

Johnson, J.S., Friend, S.B. and Malsh, A. (2016), "Mixed interpretations of sales proposal signals", Journal of Personal Selling \& Sales Management, Vol. 36 No. 3, pp. 264-280, doi.org/10.1080/08853134.2016.1205447

Kirmani, A. and Rao, A.R. (2000), "No Pain, no gain: A critical review of the literature on signaling unobservable product quality", Journal of Marketing, Vol. 64 No. 2, pp. 66-79, doi.10.1509/jmkg.64.2.66.18000 
Kozlenkova, A.V., Palmatier, R.W., Fang, E., Xiao, B. and Huang, M. (2017), “Online relationship formation”, Journal of Marketing, Vol. 81 May, pp. 21-40, doi.org/10.1509/jm.15.0430

Lanzolla, G. and Frankort, H.T.W. (2016), “The online shadow of offline signals: Which sellers get contacted in online B2B marketplaces?", Academy of Management Journal, Vol. 59 No. 1, pp. 207-231, doi.org/10.5465/amj.2014.0051

Lee, B., Ang, L. and Dubelaar, C. (2005), "Lemons on the web: A signalling approach to the problem of trust in internet commerce", Journal of Economic Psychology, Vol. 26, pp. 607623, doi.org/10.1016/j.joep.2005.01.001

Li, J., Tang, J., Jiang, L., Yen, D.C. and Liu, X. (2019), “Economic success of physicians in the online consultation market: A signalling theory perspective", International Journal of Electronic Commerce, Vol. 23 No. 2, pp. 244-271, doi.org/10.1080/10864415.2018.1564552 Li, H., Fang, Y., Wang, Y., Lim, K.H. and Liang L. (2015), "Are all signals equal? Investigating the differential effects of online signals on the sales performance of emarketplace sellers", Information Technology \& People, Vol. 28 No. 3, pp. 699-723, doi.org/10.1108/ITP-11-2014-0265

Li, S., Srinivasan, K. and Sun, B. (2009), "Internet auction features as quality signals", Journal of Marketing, Vol. 73 No. 1, pp. 75-92, doi.org/10.1509/jmkg.73.1.075

Mavlanova, T., Benbunan-Fich, R. and Koufaris, M. (2012), "Signaling theory and information asymmetry in online commerce", Information \& Management, Vol. 49, pp. 240247, doi.org/10.1016/j.im.2012.05.004 
Yen, H.J.R. (2006), “Risk-reducing signals for new online retailers: a study of single and multiple signalling effects", International Journal of Internet Marketing and Advertising, Vol. 3, No. 4, pp.299-317, doi: 10.1504/IJIMA.2006.012685 


\section{University Library}

\section{- M M N E R VA A gateway to Melbourne's research publications}

Minerva Access is the Institutional Repository of The University of Melbourne

Author/s:

Bove, L;Benoit, S

Title:

Restrict, clean and protect: Signalling consumer safety during the pandemic and beyond

Date:

2020-09-17

Citation:

Bove, L. \& Benoit, S. (2020). Restrict, clean and protect: Signalling consumer safety during the pandemic and beyond. Journal of Service Management, 31 (6), pp.1185-1202. https:// doi.org/10.1108/JOSM-05-2020-0157.

Persistent Link:

http://hdl.handle.net/11343/249359 